\title{
"DURMA" (Model Penciptaan Pesan dan Kesan Musik Melalui Pembenturan Teks Lirik dengan Ekpresi Musik)
}

\author{
Bondan Aji Manggala \\ Fakultas Seni Pertunjukan \\ Institut Seni Indonesia (ISI) Surakarta \\ Email: bondan@isi-ska.ac.id
}

\begin{abstract}
This article is part of a report on the results of artistic research (works of music) in the field of music. Briefly expresses experience and some knowledge findings related to the process of creating musical works of art. "Durma" is an editorial for this artwork, which contains three works of music with a popular music creation approach. Inspired by the anxiety of observing the infertility of creativity in the area of popular music in Indonesia, through "Durma" the thought was made to model the creativity of popular music by paying attention to the clash of lyric texts with musical expressions to produce messages and impressions of songs that are not public. In the habits of popular music, the elements of lyric text and musical expression are linear and mutually reinforcing relationships. It has never been imagined before that when a popular musical creation thinks a little freely and tries to clash ideas with an established knowledge of popular music creation, it will instead create ambiguity and the complexity of a refreshing taste. The outputs of the "Durma" artistic research include (1) art work products in the form of audio recordings of three songs entitled (a) Candles, (b) Girls, and (c) Good Night, (2) research reports, and (3) scientific publications articles that unravel the knowledge behind this work process.
\end{abstract}

Keywords : Music creation, popular, clash of musical expressions and lyric texts

\section{Pendahuluan}

Karya ini dilatarbelakangi oleh amatan mengenai fenomena model penciptaan musik populer berbasis teks lirik $^{1}$ yang dewasa ini mengalami kelesuan kreativitas, kemandegan logika pikir dan penyusutan paradigma. Secara eksplisit, wilayah penciptaan musik yang berbasis teks lirik telah terjadi pengkultusan model alur berfikir yang seolah-olah absolut tidak tergantikan, khususnya di bidang musik populer. Pengkultusan tersebut yang kemudian membuat kreativitas model penciptaan musik ini tidak berkembang secara pesat, termasuk juga melesukan industri musik populer di Indonesia.

Penciptaan musik berbasis teks lirik sebagian besar memang berkembang pada wilayah hidup musik populer. Musik populer diciptakan dan dihidupkan dari kapitalisme industri. Fungsi kapitalisme adalah membuat standarisasi ko-

1 Teks lirik adalah sajak atau puisi pendek yang dibuat untuk dinyanyikan (Kamus Besar Bahasa Indonesia). moditas, melakukan berbagai propaganda kepada masyarakat supaya menyepakati keindahan komoditas, membutuhkan, dan kemudian terikat terhadap komoditas. Pola kerja yang selalu berhubungan dengan standarisasi, menjadi muara atas kemandegan kreativitas bagi pencipta musik populer, terlebih di Indonesia. Sejak zaman popularitas musisi Edy Sud, Benyamin S., Elya Kadam, Koes Plus, hingga zaman God Bless, Dewa 19, Seventeen, sampai yang mutakhir Payung Teduh, Via Vallen, dan Nila Kharisma, struktur kekaryaan musik yang digunakan dari kesemuanya adalah sama. Setiap karya musik populer Indonesia pasti menggunakan struktur yang berurutan - (a) Intro, (b) Tema lagu pokok, (c) Reffrain, (d) Interlude, (e) Pengulangan tema dilanjutkan reffrain, dan (f) Ending - dan belum pernah terjadi gebrakan perubahan terhadap standar struktur tersebut. Mungkin terdapat ketakutan untuk tidak laku, ketika berani merubah struktur musik tersebut. Tema-tema tentang cinta dengan berbagai eksplorasi pengkisahan- 
nya, masih menjadi tema-tema teks lirik yang berkembang pada musik populer Indonesia. Terlebih pada wilayah pengekspresian musik, komposisi musik, dan pertunjukannya, jauh lebih mandeg dibandingkan wilayah kreativitas yang lain (Theodore KS, 2013: 5-95).

Kegelisahan mengamati kemandulan kreativitas pada wilayah musik populer-atau secara netral disebut kekaryaan musik berbasis teks lirik - teresapi sejak penulis mulai mengampu mata kuliah Budaya Musik Populer di Jurusan Etnomusikologi. Kemandulan kreativitas di bidang kekaryaan berbasis teks lirik ini tidak semestinya terjadi di Indonesia, karena secara kultural merupakan ladang subur atas tumbuhnya folkmusic berbasis teks lirik. Standarisasi karya (kasarnya memandulkan kreativitas kekaryaan musik populer) sebenarnya tidak berpengaruh terhadap kerugian industri musik. Paradigma industri musik di Amerika sudah menunjukkan bahwa, syarat popularitas adalah kemenangan atas kompetisi kreatif dari seniman musik populer. Di Amerika, perkembangan kreativitas musik sangat pesat. Percobaan-percobaan pengubahan kebiasaan struktur baku dari musik sudah sangat sering dilakukan; eksplorasi ekspresi musik, tema lirik, performance, bahkan tingkat estetika musik selalu tampil dengan penuh kebaruan dari masing-masing pelaku musik. Nyatanya, industri musik Amerika jauh lebih berjaya di dunia dibandingkan dengan Indonesia. Artinya, rumusan standarisasi musik yang dilakukan oleh pelaku industri musik Indonesia bukanlah rumusan yang tepat. Industri musik Indonesia harus lebih terbiasa dengan eksperimen-eksperimen kreatif yang mengupayakan kekaryaan musik berbasis teks lirik untuk selalu tampil segar dengan berbagai unsur kebaruannya.

Wilayah eksperimentasi kreatif yang akan dilakukan dalam penelitian artistik kali ini adalah melakukan pembenturan ekspresi antara dua elemen musik populer yaitu teks lirik dan ekspresi musik. Pada umumnya ada dua elemen yang dianggap penting dalam dunia musik berbasis teks lirik (populer), yakni teks vokal serta sistem kerja musikal. Dua hal tersebut dimaknai sang kreator musik pada umumnya sebagai hal yang harus memiliki relasi saling menguatkan. Misalkan, teks vokal yang betemakan penderitaan, kemudian ditafsir dengan aksentuasi bunyi akord-akord minor, tempo lambat, ritme yang renggang, melodi yang mengandung kesan sedih serta ekspresi pertunjukan yang dramatis-tragis, akan berhasil menciptakan kesan suasana emosi kesedihan mendalam. Fakta itu menandai bahwa prespektif kreator musik hingga saat ini masih berfikir kesatuan dua hal tersebut berelasi mutlak dan hanya menciptakan satu kesan suasana tunggal. Pada posisi itu, bahkan kreator musik seakan-akan mengkultuskan pendengar bahwa kesan musikal itu dapat tersampaikan melalui kesatuan dua elemen yang harus menyampaikan pesan dan kesan tunggal.

Karya ini menawarkan konsep pemikiran penciptaan yang justru berlawanan dalam memanfaatkan dua elemen penting pertunjukan musik tersebut. Bahwa, dua elemen penting dalam pertunjukan musik tidak harus selalu berelasi saling menguatkan, tetapi juga dapat diposisikan dalam relasi yang saling bertentangan. Mempertentangkan kedua elemen tersebut memang spekulatif, namun bukankah justru membuka peluang terciptanya kesan-kesan yang tidak tunggal bagi audiens karena sesungguhnya kesan suasana emosi manusia tidaklah murni tunggal. Terkadang sebuah suasana kebahagiaan berbalut dengan kesedihan, atau sebaliknya. Berbagai suasana selalu membaur dalam pengalaman kehidupan manusia. Ketika pesan dan kesan yang jamak - seperti halnya perasaan manusia-mampu dihadirkan dalam konteks karya musik berbasis teks lirik, maka dapat dibayangkan keberdayaan musik yang begitu hebat.

Lebih penting lagu, ketika kedua elemen pertunjukan tersebut diposisikan sebagai elemen-elemen mandiri dalam menyampaikan 
pesan dan kesan yang berbeda, maka akan tampak peran masing-masing elemen menjadi setara, bukan lagi elemen pendukung. Kegiatan kreatif seorang pengkarya juga lebih kompleks dan komprehensif karena memikirkan kesetaraan tiga elemen pertunjukan yang berkesan kontras. Ketika kedua elemen tersebut mampu bekerja sendiri-sendiri, bahasa di dalam teks lirik tidak lagi mampu mewakili dan memahamkan pendengar atas pesan dan kesan yang melebihi bahasa. Jika capaian itu terwujud maka musik akan sejajar dengan mitos. Seperti hal yang dijelaskan oleh Heddy Shri Ahimsa Putra bahwa:

Mitos dan musik pada dasarnya adalah bahasa. Ketika dipentaskan keduanya meminta perhatian dari struktur-struktur mental yang ada pada manusia dan keduanya memerlukan dimensi untuk mewujud. Meskipun demikian, keduanya melebihi bahasa lisan karena makna mitos dan musik tidak dapat dipahami sebagaimana kita memahami bahasa lisan, yakni kata demi kata. (Heddy Shri Ahimsa Putra, 2013: 90)

Eksperimentasi musik berbasis teks lirik dengan model pertentangan pesan dan kesan antara dua elemen pertunjukan musik ini dalam penelitian artistik kali ini dirumuskan dengan tajuk Durma. Durma merupakan terminologi pembingkai tema dari tiga karya musik yang bercerita tentang peperangan batin atau pengetahuan tentang bagian-bagian permasalahan yang dialami laki-laki menginjak masa tua. Tiga karya musik yang dihasilkan, yaitu: (1) Lilin, karya musik dengan teks lirik bertemakan kegelisahan laki-laki tua, (2) Gadis, karya musik dengan teks lirik bertemakan jatuh cinta dengan kesan musik yang memunculkan kompleksitas pertentangan batin, dan (3) Good Night, karya musik dengan teks lirik berbahasa Inggris bertemakan kecintaan laki-laki tua terhadap anaknya, yang dikemas dengan memunculkan kesan ambiguitas perasaan seorang ayah.

\section{PEMBAHASAN}

\section{A. Peluang Logis Atas Gagasan Karya}

Ide penciptaan model kekaryaan musik ini terdorong oleh proses pembacaan pustaka yang dilakukan penulis. Proses pembacaan pustaka dilakukan khususnya untuk menggali pemahaman mendasar tentang musik secara filsafati sebagai upaya menemukan kemungkinan pembentukan struktur penciptaan musik yang berbeda. Hasil dari pembacaan pustaka tersebut salah satunya adalah penemuan konstruksi pikir tentang pertentangan tiga elemen pertunjukan musik yaitu teks lirik, musik, dan pergelaran musik.

Untuk Apa Seni?, Seri Buku Humaniora UNPAR, tulisan filsuf populer Indonesia bernama Bambang Sugiharto, memberi pemahaman ulang yang mendasar mengenai musik. Pada Bab. 8 berjudul Musik dan Misterinya, Bambang Sugiharto memaparkan banyak hayatan filsafat tentang musik. Bahwa musik merupakan bentuk seni yang aneh dan memiliki efek langsung dan konkret dalam mengkondisikan perasaan manusia. Musik merupakan media seni yang mampu mengubah kondisi hati menusia dan menjelaskan kondisi batin manusia dengan berbagai karakternya, yang mungkin juga jamak (Bambang Sugiharto, 2015: 302-304). Penegasan-penegasan mengenai daya potensi musik yang berhubungan dengan perasaan diuraikan secara ringan oleh Bambang di dalam bukunya. Pendapat-pendapat tersebut disepakati oleh penulis sebagai sebuah fakta pengalaman musikal yang sering dialami. Kenyataan-kenyataan banyak pengalaman manusia perihal pendengar musik ini, menjadi akumulasi keyakinan bagi penulis untuk berfikir analitik guna mengubah hati dan menjelaskan dimensi keanekaragaman suasana batin, maka model penciptaan pertentangan tiga elemen pergelaran musik niscaya mampu menciptakan kesan musikal dan pertum- 
buhan suasana perasaan yang lebih kompleks.

Strukturalisme Levi Strauss: Mitos dan Karya Sastra yang ditulis oleh Heddy Shri Ahimsa Putra memberikan kontribusi pemikiran yang besar dalam penciptaan konsep kekaryaan ini. Karya musik yang berbasis pada teks lirik tidak dapat menghindar dari kekuatan linguistik di dalamnya. Analisis strukturalisme Levi Strauss dalam menelisik karya sastra menjadi dasar metode dan prosedur pengembangan kekaryaan ini. Baik dalam menggali unsur kesastraan dalam lirik maupun dalam pengembangan musikal. Dasar pemahaman tentang miteme (mytheme), penyusunan miteme dari elemen sintagmatis dan paradigmatis akan digunakan, diadaptasi dan dianalogikan dalam praktik pembuatan karya musik dan perumusan model kekaryaan ini.

"Kalau Bahasa dapat Diterjemahkan Mengapa Musik Tidak?” merupakan sebuah tulisan jurnal Judith Becker yang dianggap penting sebagai pustaka tertinjau. Secara garis besar, Judith menulis jurnal ini diinspirasi dari teori-teori strukturalisme Levi Strauss, yaitu tentang bagaimana menerjemahkan musik menggunakan tata cara strukturalisme untuk linguistik. Melalui tulisan Judith, semakin jelas bahwa model kekaryaan yang akan digunakan pada penelitian artistik ini memiliki peluang besar untuk diciptakan dan dilakukan.

Rock ' $n$ Roll Industri Musik Indonesia, karya Theodore KS berkisah tentang perjalanan panjang industri musik populer di Indonesia sejak awal hingga era tahun 2000-an. Buku ini banyak membantu penulis untuk menemukan berbagai persoalan industri musik dan kekaryaan di bidang musik populer termasuk kekaryaan musik berbasis teks lirik di Indonesia. Kisah-kisah Theodore ini membantu penulis menemukan permasalahan sebagai titik awal inspirasi kekaryaan ini.

\section{B. Gagasan Isi Karya "Durma"}

Kata Durma yang diadopsi dari salah satu jenis tembang macapat Jawa, digunakan untuk memayungi konsep kekaryaan tiga lagu dalam bingkai kekaryaan kreatif musik populer kali ini. Jenis-jenis tembang macapat Jawa yang antara lain Mijil, Mas Kumambang, Asmarandana, Pangkur, Sinom, Megatruh, Pocung, termasuk juga Durma, dimaknai secara filosofis sebagai gambaran siklus hidup manusia Jawa. Misalnya macapat Mijil yang menggambarkan fase kelahiran manusia, Pocung yang menggambarkan fase mati, dan lain sebagainya. Penempatan tembang macapat dalam fase-fase spesifik siklus hidup manusia ini juga mengarahkan pada isian pesan pada tembang yang menyesuaikan penceritaan problematika atas fase yang dibebankan padanya. Pada serat-serat kuno Jawa, tembang Mijil cenderung digunakan untuk menceritakan problematika masa-masa kelahiran manusia, dan Pocung digunakan untuk menceritakan perihal kematian manusia. Sedangkan Durma dimengerti sebagai tahap tengah dalam fase hidup manusia, yaitu ketika manusia (khususnya laki-laki) berada pada tahap memasuki masa tua. (Darusuprapto, 1989 : 22)

Pada beberapa serat Jawa, Durma sebagai media penjelasan problematika manusia menginjak masa tua menunjukkan bahwa laki-laki tua adalah masa penuh paradoks. Paradoks yang dimaksud adalah pertentangan antara batin dengan ekspresi raga, pertentangan antara logika berfikir realita dengan batinnya. Pada lokal jenius orang Jawa menerangkan bahwa laki-laki ketika menginjak masa tua justru diharapkan memiliki kemampuan paradoksal. Perumpamaannya, semisal, ketika laki-laki tua sedang dilanda kesedihan maka dia tidak disarankan untuk mengekspresikan kesedihannya secara fisik baik mimik wajah maupun perilaku fisik lainnya. Yang justru disarankan adalah menampakkan paradoks dari kesedihannya yaitu berupa perilaku yang tegar, kuat, bahkan mampu menenangkan lingkungan sekitarnya yang bersedih. Pengetahuan ini logis jika dikaitkan dengan peran laki-laki tua sebagai pemimpin keluarga. Ketika pemimpin keluarga tampak 
sedih, bimbang, dan bingung maka akan sangat mempengaruhi psikologis anggota keluarganya, meskipun harus dilakukan dengan menipu. Bagi lokal jenius Jawa sikap paradoksal laki-laki tua semacam inilah yang justru ditengarai sebagai sikap sempurna dari kedewasaan manusia. (Daruspuprapto, 1989: 23)

Esensi lokal jenius tentang paradoksal sikap laki-laki tua pada tembang Durma rasanya tepat digunakan sebagai spirit kekaryaan musik kali ini. Karya musik populer bergenre Rock pada projek penelitian artistik Durma ini menawarkan inovasi metode kekaryaan yang mencoba membenturkan atau membuat paradok antara ekspresi teks lirik dengan ekspresi garapan musiknya. Jika ekspresi teks lirik itu dianalogikan sebagai batin laki-laki tua Jawa, maka ekspresi garapan musiknya dilakukan dengan pendekatan yang teranalogi dari sikap fisik laki-laki tua Jawa.

\section{Gagasan Garap}

Spirit untuk menciptakan paradoks pada karya musik disikapi dengan beberapa pertimbangan kreatif. Dua elemen yang dijadikan obyek paradoks adalah antara teks lirik dengan komposisi dan aransemen musik yang membingkainya. Teks lirik diposisikan sebagai perwakilan batin yang mengungkapkan hal verbal dari kejujuran sosok imajiner laki-laki tua seperti yang ditampakkan pada tembang Durma. Sementara garapan komposisi dan aransemen musik diposisikan sebagai perwakilan ekpresi fisik maupun realitas nyata yang ditampakkan laki-laki ketika menyembunyikan batinnya.

Tema teks lirik yang dipilih adalah tema-tema realitas batin, diperkirakan diderita mayoritas laki-laki tua, yang cenderung akan disembunyikan. Antara lain adalah kesedihan laki-laki ketika menghadapi masalah, rasa jatuh cinta yang terkadang muncul kembali, dan perihal interaksi laki-laki tua dengan anaknya ketika harus menutupi sedikit realitas.

Sementara garapan musik yang digu- nakan antara lain tereferensi oleh model-model garap musikal western rock di era tahun 1990an. Pada era 1990-an berkembang trend gaya musik maskulin rock yang sangat populer di kalangan penggemar musik dunia. Kelompok musik (band) seperti Gun n' Roses, Bon Jovi, Dream Theater, dan Aerosmith menjadi garda depan pionir dari gaya musik maskulin rock yang dilahirkan karena ingin menyaingi popularitas musik Pop Madonna yang feminim (Johan Fornas, 1995: 16 -17).

Garap musikal rock di era 1990 cukup memberi gambaran tentang hasil paradok antara teks lirik yang tidak sejajar ekspresinya dengan garap musik. Pada beberapa karya lagu monumental rock di era 1990-an, beberapa di antaranya dijumpai teks lirik tentang patah hati, kerinduan mendalam, dan bentuk-bentuk ungkapan kesedihan lainnya namun terbalut dengan garapan musik yang tegas hentakan, penuh distorsi, percepatan tempo yang cepat, sehingga kesan kesedihan dari teks lirik tidak lagi terasa seperti kesedihan biasa. Suasana paradok antara teks lirik dan musik semacam inilah yang diharapkan juga dimunculkan dalam garapan karya kali ini. Meski telah terdapat rujukan dalam penggarapan karya, namun pada kesempatan proses penciptaan karya musik kali ini masih diberikan peluang ekplorasi yang besar untuk menemukan kebaruan.

\section{Bentuk Garapan Karya "Durma"}

Karya musik Durma membingkai tiga karya lagu dengan pendekatan dan upaya percobaan penciptaan paradoks yang berbeda-beda. Tiga karya lagu tersebut berjudul (1) Lilin, (2) Gadis, dan (3) Good Night.

\section{Lilin}

Pesan teks lagu Lilin dibuat untuk mengungkapkan perasaan sedih. Situasi kesedihan yang dibayangkan adalah ketika seseorang sedang dalam keadaan terpuruk, seperti 
hampir putus asa karena belum menemukan jalan keluar dari masalahnya. Pada teks lagu Lilin tidak diperjelas subyek penderita, namun menggunakan subyek analogi kebendaan yang disebut sebagai lilin. Berikut adalah teks lagu Lilin secara lengkap beserta strukturnya.

\author{
Teks Lagu \\ "Lilin" \\ $\left(\right.$ Verse $\left.^{2}\right)$ \\ Sebatang lilin \\ Ia sering takut mati \\ Terhembus angin \\ Redup nyala, nyala redup \\ Memejar pendar \\ Gelap nyaris tak tertepis \\ Terlanjur nyala \\ Lalu sepi melingkupi
}

$\left(\right.$ Chorus $\left.^{3}\right)$

Terang yang ingin ia jaga (sebenarnya)

Terang yang sebenarnya sementara $-2 x$

$\left(\operatorname{Reff}^{4}\right)$

Lilin-lilin yang berdoa

Untuk tetap terang $-2 \mathrm{x}$

(Verse 2)

Sebatang lilin

Ia sering takut mati

Terlanjur nyala

Lalu sepi melingkupi
2 Verse adalah pengantar sebuah lagu atau juga disebut sebagai bait pokok.

3 Chorus adalah inti cerita pada lagu yang menggunakan pola nada berbeda dan lebih nyaman daripada bagian verse.

4 Reff atau Reffrain adalah bagian inti pesan dari lagu (hampir sama kedudukannya dengan Chorus), namun bentuk pola nadanya lebih nyaman dari chorus dan biasanya cenderung lebih sederhana dan memorable.

\author{
$\left(\right.$ Bridge $\left.^{5}\right)$ \\ u....uu....uu...... - $4 \mathrm{x}$ \\ (Interlude $\left.{ }^{6}\right)$ \\ (Back to Reff) \\ Lilin-lilin yang berdoa \\ Untuk tetap terang $-2 \mathrm{x}$
}

\section{$\left(\mathrm{Coda}^{7}\right)$}

Sebatang lilin

Ia sering takut mati

Dilihat dari rangkaian pesan dari teks lagu Lilin di atas, rasanya cukup untuk mengungkapkan kesan kesedihan. Cukup gamblang pula kesan dari teks lagu tersebut untuk direspon dengan imajinasi musikal untuk membuat bentuk-bentuk musik yang mendayu-dayu dan lambat guna memaksimalkan kesan kesedihan yang sudah mulai ditampakkan oleh teks lagu. Namun pada proses penggarapan musik lagu Lilin, pengkarya justru berfikir sebaliknya. Pengkarya berusaha menghindari imajinasi yang linier dan mencoba mengarahkan imajinasi pada kesan paradoks dari kesan kesedihan yang terkandung dalam teks lagu.

Upaya untuk menampilkan paradoks kesan kesedihan dari teks lagu Lilin diimplementasikan secara musikal dengan beberapa langkah yang antara lain sebagai berikut.

a. Pemilihan nada dasar Bm (B Minor) yang memiliki konskuensi suara tinggi dan 'ngotot' untuk vokal pria. Karak-

5 Bridge adalah bagian yang digunakan untuk menjebatani antara bagian verse menuju chorus, chorus menuju verse, maupun verse menuju reff. Bridge biasanya menggunakan pola musikal yang berbeda dari bagian lagu lainnya.

6 Interlude merupakan bagian kosong dari lirik (instrumental, biasa dalam kebiasaan musik rock diisi dengan lead gitar) yang perannya menyerupai bridge yaitu menjembatani antar bagian lagu.

7 Coda atau disebut ekor, adalah bagian akhir lagu yang berisi nada dan teks lirik untuk menutup lagu. Umumnya coda mengambil beberapa bagian lirik dan nada yang sudah ada sebelumnya. 
teristik tingginya nada suara dan kesan ngotot saat menyanyikan lagu Lilin, bertujuan untuk mengurangi kesan kesedihan yang lemah atau lemas, tetapi justru mempu memunculkan kesan semangat dan gagah pada warna suara vokal pria.

b. Percepatan tempo untuk lagu Lilin diterapkan dalam kategori tempo cepat yaitu $140 \mathrm{bpm}$. Percepatan tempo 140 bpm membawa konsekuensi pada corak musikalitas khususnya ritmikal yang gagah dan bersemangat.

c. Gaya instrumentasi dan aransemen musik menggunakan elemen-elemen konvensional dari musik rock. Pada instrumentasi digunakan drum yang memainkan touching tegas dan pola ritmikal rock, pada gitar digunakan efek suara distorsi, dan instrumen bass yang juga menerapkan pola gaya rock. Sementara untuk menambah dramatik memunculkan kesan seram pada aransemen musik digunakan instrumen piano dan string ensemble yang meliputi violin, viola, cello, dan horn bass.

d. Pola komposisi musik dari lagu Lilin disusun berdasarkan alur dramaturgi tertentu. Pada awal lagu ditampilkan permainan piano dan vokal yang ametris (tidak mengacu kestabilan tempo). Tujuan dibuatnya bagian awal ini adalah memunculkan kesan pokok lagu yang bercerita tentang kesedihan. Kemudian pada bagian verse awal, sudah disajikan musikalitas yang mengacu pada beat-beat tegas dengan pendekatan vokal yang gagah pula. Pada bagian chorus di tengah-tengah lagu ditampilkan permainan musik combo band dengan string ensemble yang 'penuh' untuk menunjukkan klimaks lagu yang seram, beserta permainan lead gitar dengan distorsi.
Pada bagian coda akhir lagu, ditampilkan permaianan vokal dan piano yang menyerupai kesan intro lagu.

\section{Gadis}

Lagu berjudul Gadis mengambil sisi permasalahan tentang pubertas yang kadang masih dialami sebagian besar laki-laki menginjak masa tua. Pubertas laki-laki tua terkadang masih memunculkan rasa jatuh cinta kembali, menyukai lawan jenis yang lain, dan masih bernafsu untuk melihat kecantikan wanita lain. Meski masih mengalami pubertas, namun rasa itu harus ditahan sebagai polemik batin dan pikiran yang akhirnya harus dimusnahkan.

Teks lagu Gadis dibuat seolah-olah mewakili batin dan nafsu jatuh cinta seorang laki-laki. Kata-kata dan kalimat yang terbentuk dalam teks lagu ansih dibuat seyogyanya kata-kata umum yang terucap ketika laki-laki mengalami jatuh cinta. Tetapi ekspresi bernyanyi dan musik yang membingkainya menjadi perwakilan atas paradoksal sikap dari laki-laki tua yang harus menahannya dan berusaha melawan gejolak batin itu. Berikut ini adalah uraian teks lagu Gadis beserta penanda struktur lagunya.

Teks Lagu

"Gadis"

(Verse)

Hai gadis...

Hai jelita Cantik hatiku

Hai juwita...

Hai ratu tahta hatiku

(Verse 2)

Arahkan pandangmu

Hanya tertuju padaku mentariku

Arahkan senyummu

Untuk warnai, warna-warni hatiku 


\section{tatus}

(Chorus)

Gadis pintar gadis cantik tangguh mempeso-

na

(pesona tangguhmu, anggun mempesonaku) Ceriamu membawaku ke dunia penuh cinta (ke dunia penuh cinta, ke dunia cinta yang sesungguhnya)

\section{(Reff)}

Kau tak tahu bahwa

Aku menginginkanmu - 2x

Kau tak tahu bahwa

Aku menginginkanmu 2x

(interlude)

(Verse 2)

Arahkan pandangmu

Hanya tertuju padaku mentariku

(Bridge)

Gadis Cantikku... -2x

(Back to Chorus and Reff)

(Coda)

Hai gadis

Hai jelita cantik hatiku

Pendekatan garap musikal pada lagu Gadis menyerupai langkah-langkah yang dilakukan pada penggarapan lagu Lilin. Pembedanya adalah capaian kesan yang berusaha dimunculkan pada lagu Gadis adalah paradoksal rasa jatuh cinta yang dibayangkan teralami olah laki-laki tua. Percepatan tempo, Instrumentasi dan aransemen musik Gadis juga menyerupai yang terterapkan pada lagu Lilin, hanya dramatisasi musikalnya yang memang berbeda signifikan. Pada awal lagu Gadis dipaparkan suasana 'manis' dari nyanyian vokal nada medium, petikan gitar, bass, piano, dan drum. Suasana ini tertahan sampai dengan verse 2. Masuk bagian chorus, pendekatan vokal menjadi sangat kontras dengan teknik valseto memainkan nada oktaf dari nada D. Kesan suara teriak yang tertahan seperti layaknya orang marah karena kesal sengaja mulai dimunculkan pada bagian ini.

Memasuki bagian interlude, masuk unsur suara string ensemble yang memainkan kontur melodi 'seram', dan terjadi pengalihan modus nada mayor menjadi minor. Harapannya, pada puncak alur lagu tercipta suasana 'seram', yang motivasi pesannya adalah menunjukkan bahwa jatuh cinta di saat menginjak usia tua itu menyeramkan.

\section{Good Night}

Lagu Good Night berkeinginan mengungkapkan situasi ucapan salam seorang laki-laki tua kepada anaknya. Sebuah ucapan salam untuk berangkat bekerja yang tidak selalu mengesankan suasana senang, tetapi kadang menyeramkan. Seram karena pada situasi tersebut terkadang seorang laki-laki tua harus menipu anaknya, karena aktivitas yang sesungguhnya bukanlah benar-benar bekerja, yang kemudian harus merelakan waktu bercanda dengan anaknya. Gejolak rasa menipu anak dan ketidakrelaan meninggalkan waktu bercanda dengan anak inilah yang ingin dimunculkan secara musikal dalam lagu Good Night. Permainan ritmik 6/8 (enam per delapan) pada percepatan tempo 140 bpm, ditambah dengan permainan gitar, bass dan drum yang rapat bermaksud untuk mengetengahkan suasana 'seram' dalam lagu ini. Warna suara ragam lonceng dan suara matrix menjadi pilihan style tone keyboard, menambah keseraman suasana yang diciptakan pada lagu Good Night.

Berikut ini adalah uraian teks lagu Good Night beserta strukturnya. 
Teks Lagu

"Good Night"

(Verse)

Good night my daughter

Good night my little angel $2 x$

Have a nice dream $2 \mathrm{x}$

Daddy has to work $4 \mathrm{x}$

But only you in my mind

But only you in my heart

$$
\begin{gathered}
\text { (reff) } \\
\text { Oh... sorry }
\end{gathered}
$$

I have to lie to you

Oh... sorry

I should joke more with you

\section{(Verse 2)}

Daddy must go to work

Daddy has to go to work

But only you in my mind

But only you in my heart

(back to reff)

Oh... sorry

I have to lie to you

Oh... sorry

I should joke more with you

(interlude)

(Chorus)

Oh..... sorry

I have to lie to you

Oh... sorry $2 \mathrm{x}$

(Verse)

Good night my daughter

Good night my little angel 2x

\section{Penutup}

Luaran penelitian artistik (karya seni) berjudul Durma kali ini agak menyimpang dari target awal yang direncanakan. Penelitian artistik ini semula merencanakan bentuk pergelaran hasil karya musik sebagai luaran akhir, namun karena pertimbangan biaya penyelenggaraan pementasan yang rupanya jauh di atas biaya terencana akhirnya penelitian ini mengalihkan luaran karya dengan menghasilkan produk rekaman karya yang ideal. Selain kendala biaya yang tidak cukup, batasan waktu produksi karya untuk penelitian artistik pada pendanaan DIPA ISI Surakarta 2019 gelombang kedua yang hanya menyediakan waktu 2 (dua) bulan rasanya memberatkan jika luaran karya tetap diwujudkan dalam bentuk pementasan karya.

Secara esensial terdapat capaian konseptual yang akhirnya tidak tercapai. Di mana semula penelitian artistik ini membayangkan akan melakukan pembenturan ekspresi juga pada ranah pertunjukan (selain pembenturan ekspresi teks lagu dengan musik). Meski demikian capaian konseptual yang hanya berupa pembenturan ekspresi teks lagu dengan ekspresi musik tetap dilakukan secara optimal dan melahirkan pengalaman teoritik, metodik, maupun estetis bagi pengkarya.

Dengan demikian maka luaran karya pada penelitian artistik Durma kali ini melahirkan 3 (tiga) track rekaman musik format wav dalam CD (Compact Disk) yang antara lain berjudul (1) Lilin (6.01 menit), (2) Gadis (4.35 menit), dan (3) Good Night (3.27 menit). Selain juga melahirkan laporan tertulis dan deskripsi karya.

Have a nice dream $2 \mathrm{x}$ 


\section{Daftar Pustaka}

Bambang Sugiharto. "Untuk Apa Seni?”. Bandung: Pustaka Matahari. 2015

Darusuprapto. "Macapat dan Santiswara". Yogyakarta: Fakultas Sastra dan Kebudayaan UGM. 1989

Dieter Mack. “Sejarah Musik Jilid 4”. Yogyakarta: Pusat Musik Liturgi. 1995

Heddy Shri Ahimsa Putra. "Strukturalisme LeviStrauss: Mitos dan Karya Sastra”. Yogyakarta: Kepel Press. 2013

Ignatia Karina. Interpretasi Makna Macapat dalam Karya Piano Trio. Yogyakarta: Fakkultas Seni Pertunjukan Institut Seni Indonesia Yogyakarta. 2018

Johan Fornas. "The Future of Rock: Discourses That Struggle to Define a Genre". Cambrige University Press. 1995.

Lono Simatupang. "Pergelaran: Sebuah Mozaik Penelitian Seni-Budaya”. Yogyakarta: Jalasutra. 2013

Marc Perlman, dkk. "Seni Pertunjukan Indonesia”, Tahun I no.1. Surakarta: Yayasan Masyarakat Musikologi Indonesia. 1990

RMA Harymawan. "Dramaturgi”. Bandung: PT. Remaja Rosdakarya. 1993

Theodore KS. "Rock 'n Roll Industri Musik Indonesia dari Analog ke Digital”. Jakarta: PT. Kompas Media Nusantara. 2013

Vance Ferrell. "Inside Rock Music". Altamont America: Evolution Facts. Inc. 2006 